\title{
MERDEKA BELAJAR
}

11 Desember 2019

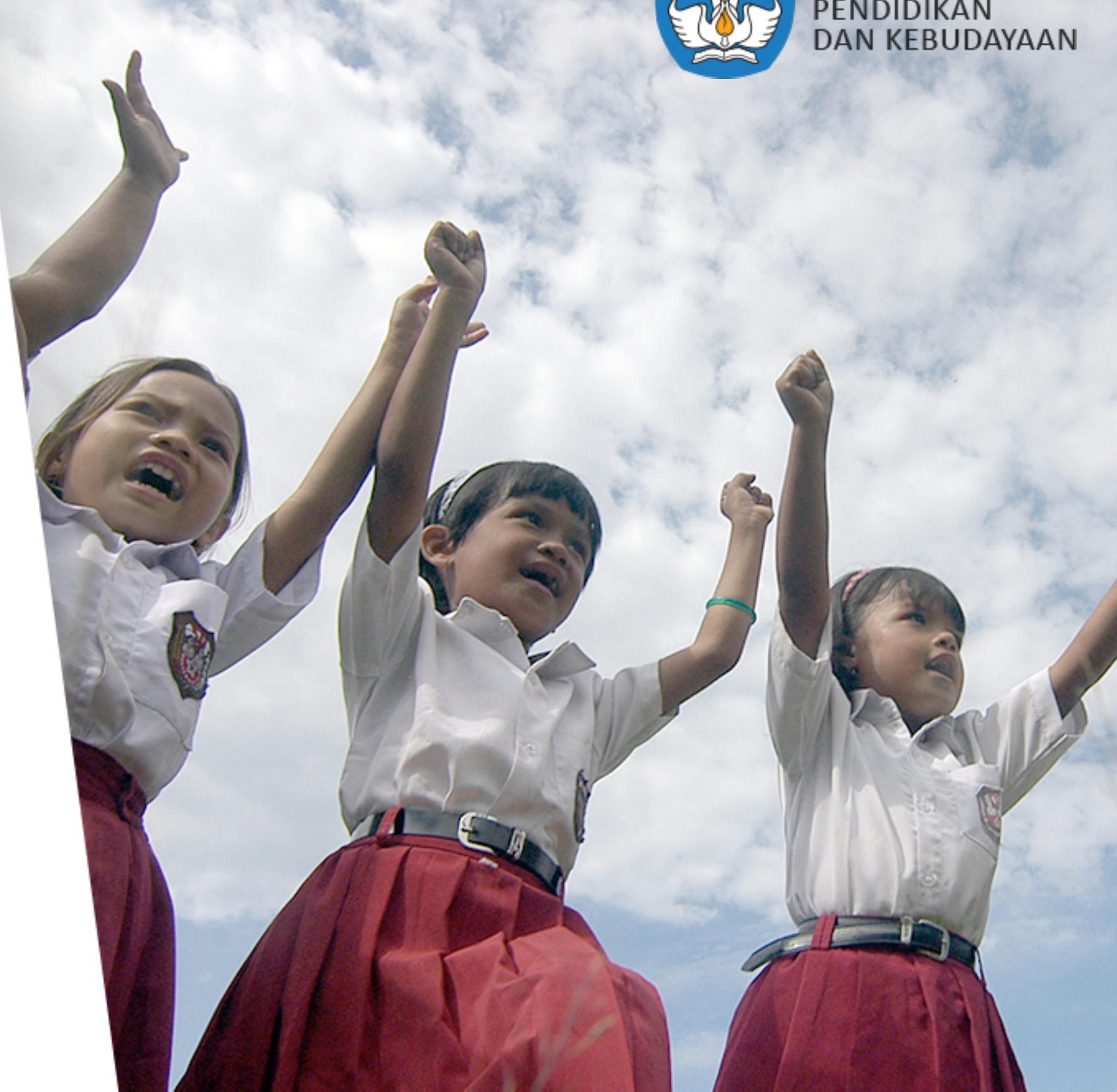




\section{Pokok-pokok Kebijakan Merdeka Belajar}

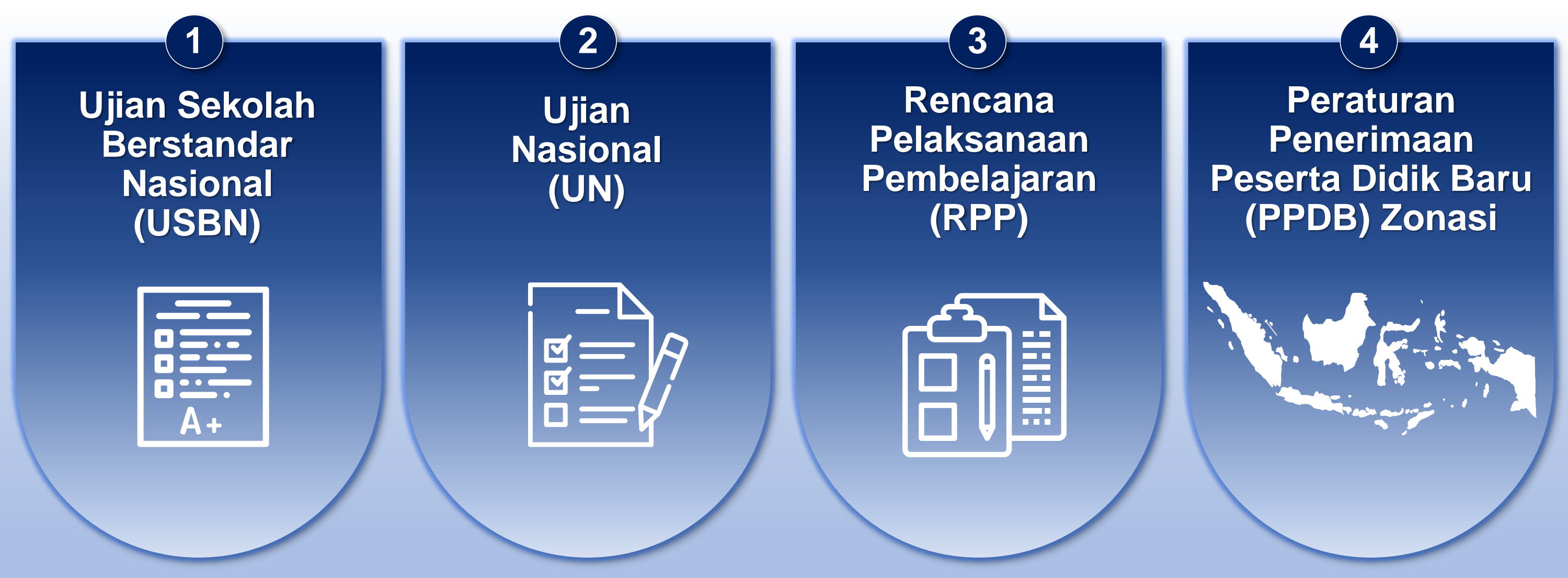




\section{(1) Ujian Sekolah Berstandar Nasional (USBN)}
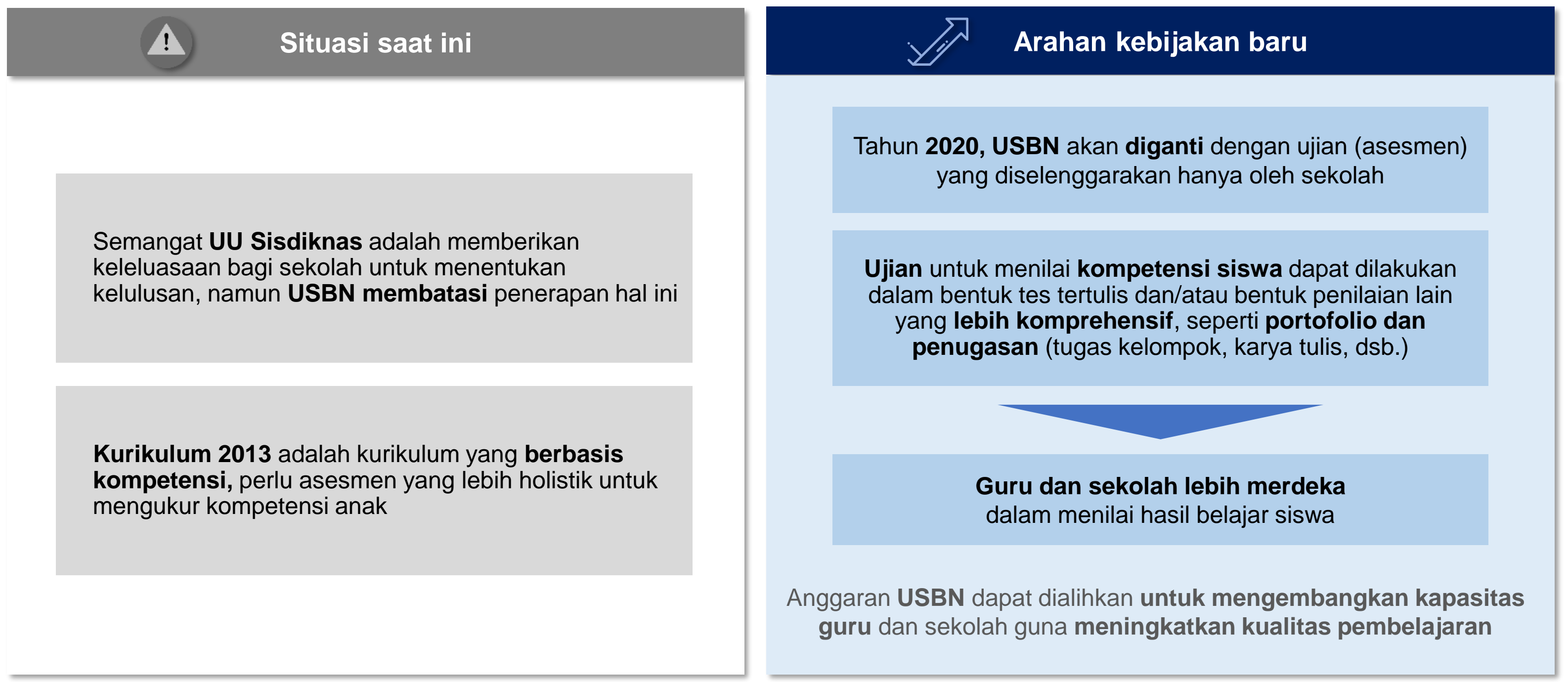

Tahun 2020, USBN akan diganti dengan ujian (asesmen) yang diselenggarakan hanya oleh sekolah

keleluasaan bagi sekolah untuk menentukan

kelulusan, namun USBN membatasi penerapan hal ini

kompetensi, perlu asesmen yang lebih holistik untuk

Guru dan sekolah lebih merdeka

dalam menilai hasil belajar siswa

Anggaran USBN dapat dialihkan untuk mengembangkan kapasitas guru dan sekolah guna meningkatkan kualitas pembelajaran

Ujian untuk menilai kompetensi siswa dapat dilakukan dalam bentuk tes tertulis dan/atau bentuk penilaian lain yang lebih komprehensif, seperti portofolio dan penugasan (tugas kelompok, karya tulis, dsb.) 


\section{(2) Ujian Nasional (UN)}

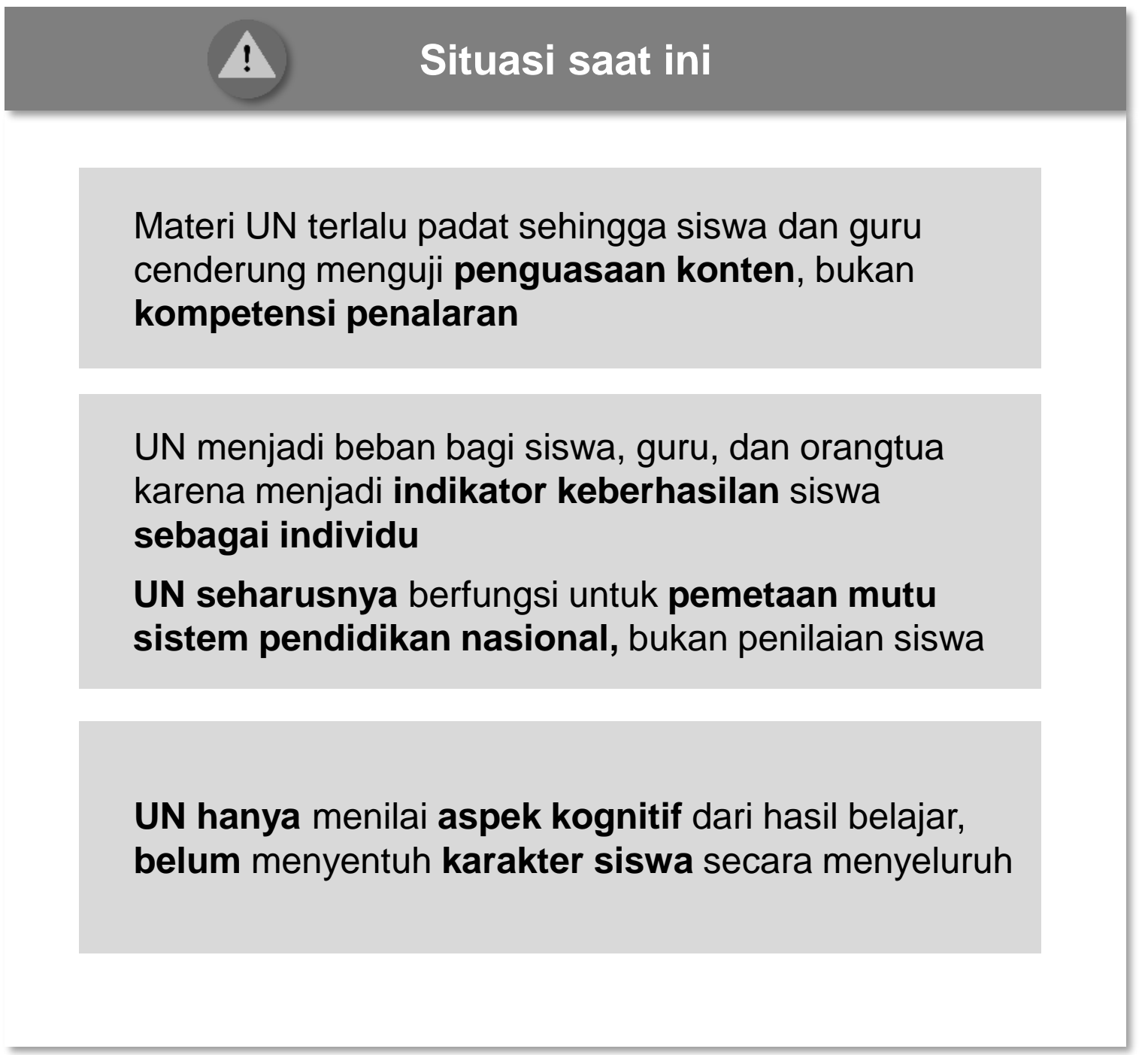

\section{Arahan kebijakan baru}

- Tahun 2020, UN akan dilaksanakan untuk terakhir kalinya

- Tahun 2021, UN akan diubah menjadi Asesmen Kompetensi Minimum dan Survei Karakter

\section{Literasi \\ Kemampuan \\ bernalar tentang \\ dan menggunakan \\ bahasa}

Numerasi
Kemampuan
bernalar
menggunakan
matematika

Numerasi

bernalar

matematika

\section{Karakter}

Misalnya pembelajar, gotong royong, kebhinnekaan, dan perundungan
- Dilakukan pada siswa yang berada di tengah jenjang sekolah (misalnya kelas $4,8,11$ ) sehingga mendorong guru dan sekolah untuk memperbaiki mutu pembelajaran dan tidak bisa digunakan untuk basis seleksi siswa ke jenjang selanjutnya

- Mengacu pada praktik baik pada level internasional seperti PISA dan TIMSS 


\section{(3) Rencana Pelaksanaan Pembelajaran (RPP)}
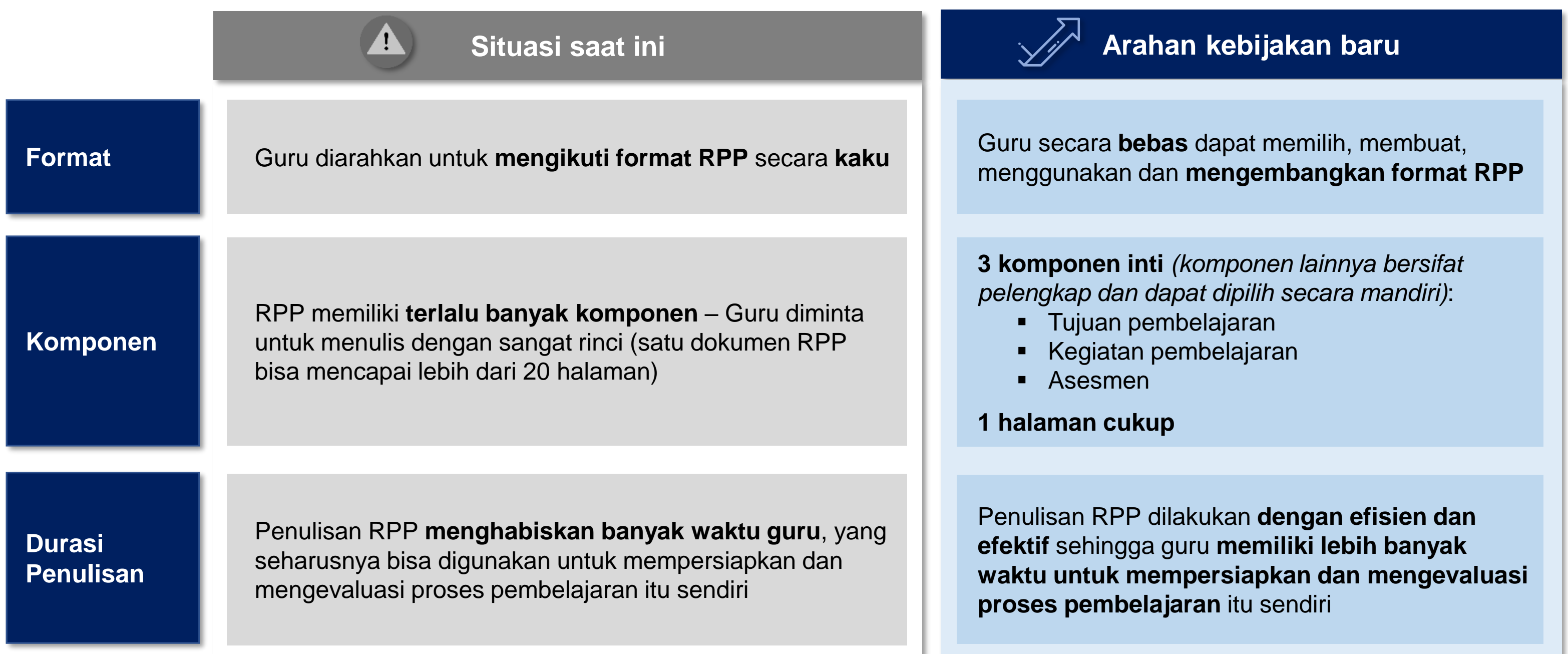

Guru secara bebas dapat memilih, membuat, menggunakan dan mengembangkan format RPP

3 komponen inti (komponen lainnya bersifat pelengkap dan dapat dipilih secara mandiri):

- Tujuan pembelajaran

- Kegiatan pembelajaran

- Asesmen

\section{1 halaman cukup}

Penulisan RPP dilakukan dengan efisien dan efektif sehingga guru memiliki lebih banyak waktu untuk mempersiapkan dan mengevaluasi proses pembelajaran itu sendiri 


\section{(4) Peraturan Penerimaan Peserta Didik Baru (PPDB) Zonasi}

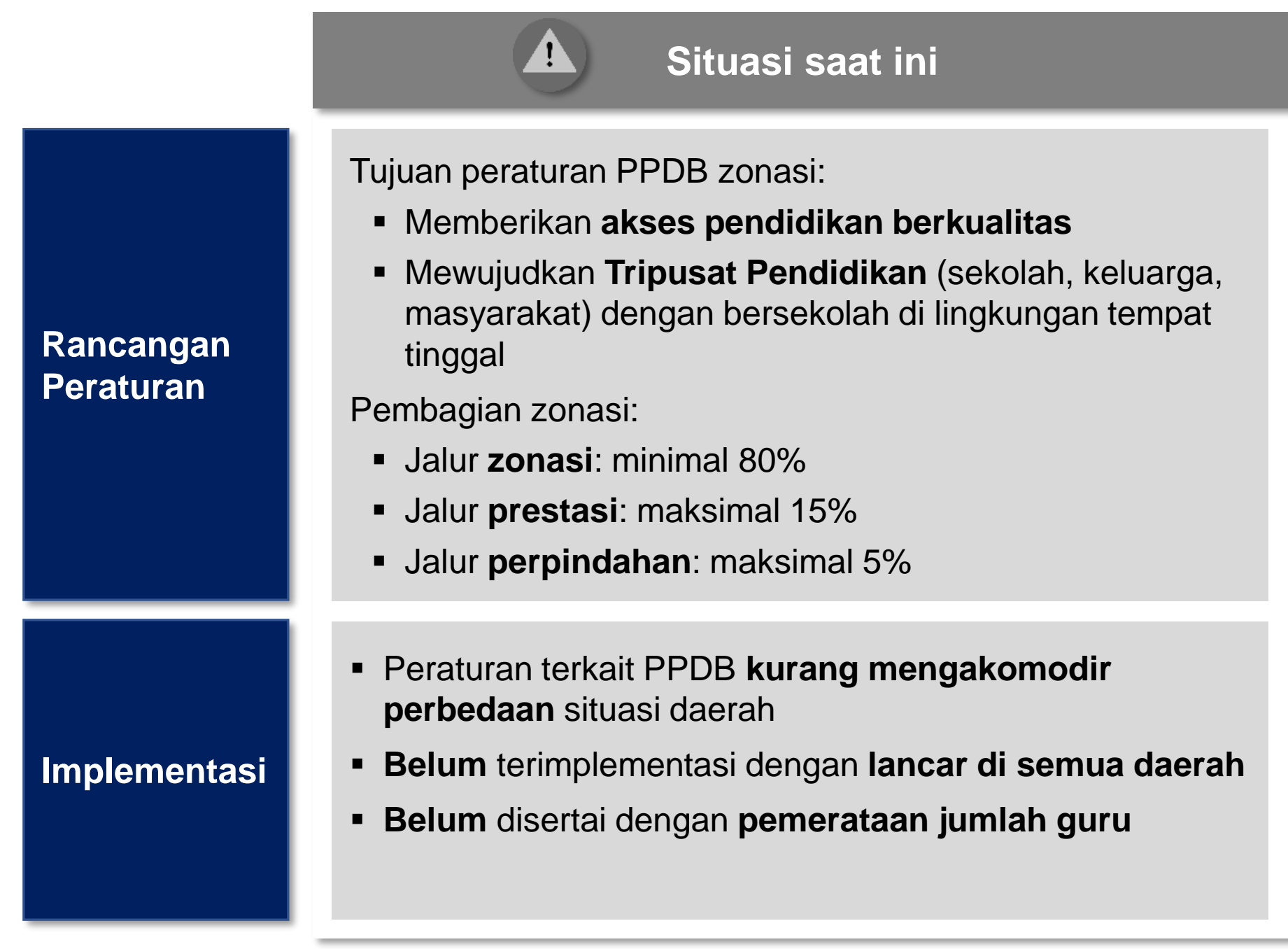

\section{Arahan kebijakan baru}

Membuat kebijakan PPDB lebih fleksibel untuk mengakomodasi ketimpangan akses dan kualitas di berbagai daerah:

- Jalur zonasi : minimal $50 \%$

- Jalur afirmasi: minimal $15 \%$

- Jalur perpindahan: maksimal $5 \%$

- Jalur prestasi (sisanya 0-30\%, disesuaikan dengan kondisi daerah)

- Daerah berwenang menentukan proporsi final dan menetapkan wilayah zonasi

- Pemerataan akses dan kualitas pendidikan perlu diiringi dengan inisiatif lainnya oleh pemerintah daerah, seperti redistribusi guru ke sekolah yang kekurangan guru 


\section{Daftar Tanya Jawab Kebijakan Ujian Sekolah Berstandar Nasional (USBN)}

\section{Mengapa pemerintah mengganti USBN?}

USBN dikembalikan pada esensinya, yaitu asesmen akhir jenjang yang dilakukan oleh guru dan sekolah. Kelulusan siswa pada akhir jenjang memang merupakan wewenang sekolah yang didasarkan pada penilaian oleh guru. Hal ini sesuai dengan UU Sisdiknas dan juga prinsip pendidikan bahwa yang paling memahami siswa adalah guru.

Selain itu, asesmen akhir jenjang oleh sekolah memungkinkan penilaian yang lebih komprehensif, yang tidak hanya didasarkan pada tes tertulis pada akhir tahun. Hal ini juga mendorong sekolah untuk mengintensifkan dan memperluas pelibatan guru dalam semua tingkat dalam proses asesmen.
Apa ganti USBN?

Seperti apa pelaksanaan ujian sekolah pengganti USBN?
Gantinya adalah ujian yang dikelola tiap-tiap sekolah. Ujian tersebut dapat dilaksanakan dalam beragam bentuk asesmen sesuai dengan kompetensi yang diukur.

Dari sisi bentuk ujian, guru boleh dan diharapkan menggunakan beragam bentuk asesmen. Hal ini bisa berupa tes tertulis seperti saat ini. Namun guru juga disarankan menggunakan asesmen bentuk lain seperti penugasan, portofolio siswa, dan project kolaboratif.

Dari sisi waktu pelaksanaan, asesmen yang menjadi bagian dari ujian ini tidak selalu harus dilakukan di penghujung tahun ajaran sebagaimana ujian konvensional selama ini. Misalnya, nilai ujian akhir jenjang bisa didasarkan pada penilaian portofolio dan penugasan yang dilakukan sejak semester ganjil.

Kedua perubahan ini memungkinkan kompetensi siswa dinilai secara lebih komprehensif. Perubahan ini juga memungkinkan penilaian yang lebih terdiferensiasi, sesuai dengan kebutuhan individual siswa.

\section{Bagaimana jika guru merasa kurang siap melakukan penilaian akhir jenjang?}

USBN memposisikan sebagian besar guru sebagai penerima dan pengguna tes yang dikembangkan oleh pemerintah pusat dan Musyawarah Guru Mata Pelajaran (MGMP) di bawah koordinasi dinas pendidikan daerah. Semua siswa dan semua sekolah dalam satu daerah terikat untuk menggunakan bentuk ujian sama.

Hal ini menghambat kemerdekaan guru untuk belajar melakukan asesmen. Dengan mengembalikan kewenangan penilaian akhir jenjang pada sekolah, guru didorong untuk mulai dan secara terus menerus mengembangkan kapasitas profesionalnya terkait asesmen.

Selain itu, membuat soal tes tertulis yang bermutu memang tidak mudah. Kabar baiknya, penilaian akhir jenjang tidak harus mengandalkan tes tertulis. Guru bisa menggunakan beragam bentuk 
asesmen yang sesuai dengan kompetensi yang diukur, termasuk bentuk asesmen yang lebih dikenal oleh masing-masing guru.

Apa peran yang diharapkan dari dinas pendidikan?
Dinas Pendidikan tidak lagi mengkoordinasi atau memfasilitasi penyelenggaraan ujian yang seragam. Peran Dinas diharapkan bergeser ke arah pengembangan kapasitas guru dan sekolah guna meningkatkan mutu pembelajaran.

\section{Apa konsekuensi kebijakan baru ini pada guru?}

Guru menjadi lebih merdeka dalam mengajar dan melakukan asesmen siswa. Guru dapat melakukan asesmen yang lebih sesuai untuk kebutuhan siswa dan situasi kelas/sekolahnya. Hal ini juga mendorong guru untuk terus mengembangkan kompetensi profesionalnya, terutama terkait asesmen siswa.

\section{Apa konsekuensi kebijakan baru ini bagi sekolah?}

Sekolah perlu mendukung praktik asesmen yang baik, yakni asesmen yang berdampak positif pada proses dan hasil belajar siswa. Hal ini bisa dilakukan dengan memfasilitasi guru untuk berkolaborasi mengenai strategi asesmen yang tepat bagi siswa dan kondisi sekolah masingmasing.

\section{Apa konsekuensi kebijakan baru ini bagi siswa?}

Tekanan psikologis bagi siswa akan berkurang karena asesmen dapat dilakukan secara lebih komprehensif, tidak hanya pada waktu spesifik di akhir tahun ajaran seperti praktik selama ini. Siswa bisa memiliki lebih banyak kesempatan, dan melalui lebih banyak cara, untuk menunjukkan kompetensinya. 


\section{Daftar Tanya Jawab Kebijakan Ujian Nasional (UN)}

\author{
Apa kebijakan baru \\ tentang UN?
}

Mulai tahun 2021 UN akan diganti dengan Asesmen Kompetensi Minimum dan Survei Karakter. Kedua asesmen baru ini dirancang khusus untuk fungsi pemetaan dan perbaikan mutu pendidikan secara nasional.

\section{Mengapa 2020 akan menjadi tahun terakhir bagi UN?}

Pertama, UN lebih banyak berisi butir-butir yang mengukur kompetensi berpikir tingkat rendah. Hal ini tidak sejalan dengan tujuan pendidikan yang ingin mengembangkan kemampuan berpikir tingkat tinggi serta kompetensi lain yang lebih relevan dengan Abad 21, sebagaimana tercermin pada Kurikulum 2013.

Kedua, UN kurang mendorong guru menggunakan metode pengajaran yang efektif untuk mengembangkan kemampuan berpikir tingkat tinggi. Asesmen kompetensi pengganti UN akan dirancang memberi dorongan lebih kuat ke arah pengajaran yang inovatif dan berorientasi pada pengembangan penalaran, bukan hafalan.

Ketiga, UN kurang optimal sebagai alat untuk memperbaiki mutu pendidikan secara nasional. Karena dilangsungkan di akhir jenjang, hasil UN tidak bisa digunakan untuk mengidentifikasi kebutuhan belajar siswa dan memberi bantuan yang sesuai dengan kebutuhan tersebut.

Apa akan mengganti UN? Asesmen kompetensi pengganti UN mengukur kompetensi bernalar yang dapat digunakan untuk menyelesaikan masalah di berbagai konteks, baik personal maupun profesional (pekerjaan). Saat ini kompetensi apa saja yang akan diukur masih dikaji, namun contohnya adalah kompetensi bernalar tentang teks (literasi) dan angka (numerasi).

Selain itu, Kemdikbud juga akan melakukan survei untuk mengukur aspek-aspek lain yang mencerminkan penerapan Pancasila di sekolah. Hal ini mencakup aspek-aspek karakter siswa (seperti karakter pembelajar dan karakter gotong royong) dan iklim sekolah (misalnya iklim kebinekaan, perilaku bullying, dan kualitas pembelajaran).

Karena fungsi utamanya adalah sebagai alat pemetaan mutu, asesmen kompetensi dan survei pembinaan Pancasila ini belum tentu dilaksanakan setiap tahun, dan belum tentu harus diikuti oleh semua siswa.

Tanpa UN, bukankah siswa kurang termotivasi untuk belajar?
Menggunakan ancaman ujian untuk mendorong belajar akan berdampak negatif pada karakter siswa. Jika dilakukan terus menerus, siswa justru akan menjadi malas belajar jika tidak ada ujian. Dengan kata lain, siswa menjadi terbiasa belajar sekedar untuk mendapat nilai baik dan menghidari nilai jelek. Hal ini membuat siswa lupa akan kenikmatan intrinsik yang bisa diperoleh dari proses belajar itu sendiri. 
Padahal, motivasi belajar intrinsik inilah yang justru sangat perlu dikembangkan agar siswa agar menjadi pembelajar sepanjang hayat.

Tanpa UN, apakah siswa tidak menjadi orang yang kurang gigih?
UN adalah alat untuk melakukan monitoring dan evaluasi mutu sistem pendidikan. Fungsi UN bukan untuk melatih keuletan atau kegigihan. Sifat-sifat ini tidak dapat dibentuk secara instan di akhir jenjang pendidikan melalui ancaman ketidaklulusan atau nilai buruk. Sifat seperti kegigihan hanya dapat ditumbuhkan melalui proses belajar yang memberi berbagai tantangan bermakna secara berkelanjutan. Butuh waktu bertahun-tahun untuk bisa membuat sifat seperti kegigihan menjadi bagian dari karakter siswa.
Mengapa hanya difokuskan pada literasi dan numerasi?
Literasi dan numerasi adalah kompetensi yang sifatnya general dan mendasar. Kemampuan berpikir tentang, dan dengan, bahasa serta matematika diperlukan dalam berbagai konteks, baik personal, sosial, maupun profesional. Dengan mengukur kompetensi yang bersifat mendasar (bukan konten kurikulum atau pelajaran), pesan yang ingin disampaikan adalah bahwa guru diharapkan berinovasi mengembangkan kompetensi siswa melalui berbagai pelajaran melalui pengajaran yang berpusat pada siswa.
Apakah berarti pelajaran selain bahasa dan matematika tidak penting?
Fokus asesmen adalah kompetensi berpikir, sehingga hasil pengukuran tidak sekedar mencerminkan prestasi akademik pelajaran Bahasa Indonesia dan Matematika saja. Literasi dan numerasi justru bisa dan seharusnya memang dikembangkan melalui berbagai mata pelajaran, termasuk IPA, IPS, kewarganegaraan, agama, seni, dst. Pesan ini penting dipahami oleh guru, sekolah, dan siswa untuk meminimalkan risiko penyempitan kurikulum pada pelajaran Bahasa Indonesia dan Matematika.
Jika apa yang diukur tidak terikat pada konten kurikulum, bagaimana kaitan antara asesmen ini dengan standar pendidikan?
Betul bahwa asesmen ini tidak terikat secara erat dengan konten kurikulum. Namun tidak berarti bahwa asesmen ini sama sekali terlepas dari kurikulum. Dari sisi konten, asesmen literasi dan numerasi tentu memperhatikan apa yang (seharusnya) diajarkan oelh guru pada tiap kelas dan jenjang pendidikan. Hanya saja, asesmen ini tidak dimaksudkan untuk mengukur penguasaan siswa atas konten kurikulum secara keseluruhan.

Pada prinsipnya, penguasaan kurikulum secara utuh hanya bisa dinilai oleh guru menggunakan sumber informasi yang beragam dari interaksi sehari-hari dengan siswa. Terlebih lagi, kurikulum tiap sekolah bisa berbeda karena masing-masing memiliki kewenangan untuk mengembangkan kurikulum yang sesuai dengan visi dan 
karakteristik siswanya.

Siapa yang akan menjadi peserta asesmen pengganti UN?
Asesmen kompetensi baru akan dilakukan pada siswa yang duduk di pertengahan jenjang sekolah, seperti kelas 4 untuk SD, kelas 8 untuk SMP, dan kelas 11 untuk SMA. Dengan dilakukan pada tengah jenjang, hasil asesmen bisa dimanfaatkan sekolah untuk mengidentifikasi kebutuhan belajar siswa. Dengan dilakukan sejak jenjang SD, hasilnya dapat menjadi deteksi dini bagi permasalahaan mutu pendidikan nasional.
Apakah perubahan ini berdampak pada siswa SD?
Perlu diketahui bahwa saat ini pun tidak ada UN pada jenjang SD. Dengan demikian, penghentian UN tidak berdampak pada siswa SD. Seperti yang dipaparkan pada poin sebelumnya, sebagian siswa SD akan mengikuti asesmen kompetensi baru. Namun asesmen baru ini dirancang agar tidak memiliki konsekuensi bagi siswa. Karena itu, asesmen baru tidak menjadi beban tambahan bagi siswa SD.
Tanpa UN, bagaimana mengukur ketercapaian standar nasional pendidikan?
Perlu dipahami bahwa UN itu sendiri bukan merupakan standar. UN merupakan instrumen asesmen yang membantu menilai pencapaian sebagian standar nasional pendidikan. Karena itu, menghapus UN bukan berarti menghilangkan standar pendidikan.

Sebagaimana disebutkan di atas, UN akan diganti dengan asesmen lain yang memang dirancang sebagai alat pemetaan mutu pendidikan nasional. Hasil asesmen pengganti UN tersebut akan menjadi indikator bagi ketercapaian standar nasional pendidikan di tiap daerah.
Jika tidak terikat pada konten kurikulum, apakah asesmen ini akan menjadi tambahan beban bagi siswa/guru di luar kurikulum yang ada?

Jika digunakan untuk menilai efektivitas sekolah, apakah asesmen baru tidak berdampak negatif pada siswa?
Asesmen yang dilakukan oleh otoritas (dalam hal ini Kemendikbud) berpotensi dipandang sebagai beban tambahan karena guru dan sekolah ingin memperoleh hasil yang baik. Meski demikian, sebenarnya asesmen literasi dan numerasi ini bukan beban tambahan. Yang diukur oleh asesmen ini bukanlah penguasaan konten tambahan yang perlu diajarkan di luar kurikulum yang ada. Seperti telah disebutkan sebelumnya, kompetensi literasi dan numerasi bisa dan perlu dikembangkan melalui semua mata pelajaran.

Harus diakui bahwa asesmen baru dapat dianggap bersifat high stakes bagi guru dan sekolah. Jika itu terjadi, asesmen baru berpotensi memiliki dampak negatif seperti mendorong adanya tekanan dari guru pada siswa untuk mendapat skor tinggi, serta anggapan bahwa pelajaran yang dianggap tidak relevan untuk asesmen ini kurang penting.

Dampak seperti ini akan dimitigasi melalui berbagai cara. Yang pertama adalah rancangan kebijakan yang menekankan pada pemberian dukungan dan sumberdaya sesuai kebutuhan sekolah, bukan hukuman dan hadiah. Kedua, akan tersedia asesmen yang sama 
dalam versi yang dapat digunakan oleh guru sebagai bagian dari pengajaran sehari-hari. Versi "asesmen mandiri" ini juga akan dilengkapi dengan petunjuk pedagogis dan sumberdaya belajar yang relevan untuk mengembangkan kompetensi siswa sesuai levelnya.

Apa dampak asesmen baru bagi siswa?
Asesmen kompetensi pengganti UN akan dirancang agar tidak memiliki konsekuensi bagi siswa. Misalnya, pelaksanaan pada pertengahan jenjang (bukan akhir jenjang) membuat hasil asesmen kompetensi tidak relevan untuk menilai pencapaian siswa. Hasilnya juga tidak relevan untuk seleksi memasuki jenjang sekolah yang lebih tinggi. Dengan demikian, asesmen ini tidak akan menjadi beban tambahan bagi siswa, di luar beban belajar normal yang sudah dijalani.
Apa dampak asesmen pada guru dan sekolah?
Analisis dan laporan hasil asesmen kompetensi akan dibuat agar bisa dimanfaatkan guru dan sekolah untuk memperbaiki proses belajar mengajar. Hal ini dimungkinkan karena asesmen baru akan didasarkan pada model learning progression (lintasan belajar) yang akan menunjukkan posisi siswa dalam tahapan perkembangan suatu kompetensi.

Laporan hasil asesmen juga akan dirancang agar tidak menjadi ancaman bagi guru dan sekolah. Pemerintah menyadari bahwa baik buruknya pencapaian siswa dipengaruhi oleh faktor pengajaran (proses di sekolah) maupun faktor-faktor di luar sekolah, seperti lingkungan rumah dan gaya pengasuhan orangtua. Karena itu keberhasilan guru atau sekolah tidak akan dinilai berdasarkan level kompetensi siswa di satu waktu. Keberhasilan guru/sekolah akan lebih didasarkan pada perubahan dan kemajuan yang dicapai dibanding waktu asesmen sebelumnya.

Hasil asesmen justru akan digunakan untuk mengidentifikasi kebutuhan sekolah. Kemdikbud akan mengalokasikan dukungan misalnya dalam bentuk alokasi SDM dan/atau dana - sesuai dengan kebutuhan tiap sekolah.

\section{Apa dasar hukum penggantian UN dengan asesmen baru?}

UU Sisdiknas secara eksplisit memberi mandat kepada pemerintah melalui lembaga mandiri - untuk melakukan evaluasi mutu sistem pendidikan nasional. Asesmen pengganti UN akan menjadi instrumen untuk melayani fungsi tersebut.

Selain itu, pengadilan Negeri Jakarta pada 2007, dan kemudian Mahkamah Agung (MA) pada 2009, menilai bahwa UN tidak adil bagi siswa yang berada di sekolah dan/atau daerah yang kekurangan sumberdaya. MA memerintahkan pemerintah untuk "meninjau kembali sistem pendidikan nasional". Dengan merancang asesmen baru yang berfungsi untuk pemetaan mutu serta umpan balik bagi sekolah, tanpa ada konsekuensi pada siswa, pemerintah secara otomatis telah mematuhi putusan hukum MA mengenai UN. 


\title{
Daftar Tanya Jawab Rencana Pelaksanaan Pembelajaran (RPP)
}

\author{
Apa yang menjadi \\ pertimbangan \\ penyederhanaan RPP? \\ Guru-guru sering diarahkan untuk menulis RPP dengan sangat rinci \\ sehingga banyak menghabiskan waktu yang seharusnya bisa lebih \\ difokuskan untuk mempersiapkan dan mengevaluasi proses \\ pembelajaran itu sendiri.
}

\section{Apa yang dimaksud dengan prinsip efisien, efektif dan berorientasi pada murid?}

- Efisien berarti penulisan RPP dilakukan dengan tepat dan tidak menghabiskan banyak waktu dan tenaga.

- Efektif berarti penulisan RPP dilakukan untuk mencapai tujuan pembelajaran.

- Berorientasi pada murid berarti penulisan RPP dilakukan dengan mempertimbangkan kesiapan, ketertarikan, dan kebutuhan belajar murid di kelas.
Apakah RPP dapat dibuat dengan singkat, misalnya hanya satu halaman?
Bisa saja, asalkan sesuai dengan prinsip efisien, efektif, dan berorientasi kepada murid. Tidak ada persyaratan jumlah halaman.
Apakah ada standar baku untuk format penulisan RPP?
Tidak ada. Guru bebas membuat, memilih, mengembangkan, dan menggunakan RPP sesuai dengan prinsip efisien, efektif, dan berorientasi pada murid.

\section{Bagaimana dengan format RPP yang sudah dibuat guru?}

- Guru dapat tetap menggunakan format RPP yang telah dibuatnya.

- Guru dapat pula memodifikasi format RPP yang sudah dibuat sesuai dengan prinsip efisien, efektif, dan berorientasi kepada murid.

\section{Berapa jumlah komponen dalam RPP?}

- Ada 3 komponen inti, yaitu tujuan pembelajaran, langkahlangkah pembelajaran (kegiatan), dan penilaian pembelajaran (asesmen). Komponen-komponen lainnya adalah pelengkap.

- Tujuan pembelajaran ditulis dengan merujuk kepada kurikulum dan kebutuhan belajar murid. Kegiatan belajar dan asesmen dalam RPP ditulis secara efisien. 


\section{Daftar Tanya Jawab Kebijakan Zonasi Tahun Ajaran 2020/2021}

\section{Perubahan Aturan}

Apa perubahan yang paling nyata dari peraturan yang baru?
Dalam Permendikbud terbaru terkait PPDB, Pemerintah Pusat memberikan fleksibilitas daerah dalam menentukan alokasi untuk siswa masuk ke Sekolah melalui jalur zonasi, jalur afirmasi, jalur perpindahan orangtua/wali, atau jalur lainnya (dapat berupa jalur prestasi). Persentasenya pun berubah menjadi sebagai berikut:

\begin{tabular}{|c|c|}
\hline $\begin{array}{c}\text { Permendikbud PPDB } \\
\text { Sebelumnya }\end{array}$ & $\begin{array}{c}\text { Permendikbud PPDB Terbaru } \\
\text { (Permendikbud No. 51 Tahun } \\
\text { 2018 jo Permendikbud No. 20 } \\
\text { Tahun 2019) }\end{array}$ \\
\hline $\begin{array}{c}\text { - Jalur zonasi minimal 80\% } \\
\text { - Jalur prestasi maksimal 15\% }\end{array}$ & - Jalur zonasi minimal 50\% \\
- Jalur perpindahan & - Jalur afirmasi minimal 15\% \\
orangtua/wali maksimal 5\% & - Jalur perpindahan \\
& orangtua/wali maksimal 5\% \\
& - Jika ada sisa kuota, jalur \\
& prestasi dapat dibuka, bisa \\
& berdasarkan UN ataupun \\
& prestasi akademik dan non- \\
& akademik lainnya. Jalur ini, \\
& dengan demikian, maksimal \\
& 30\% \\
\hline
\end{tabular}

Aturan PPDB ini dirancang agar daerah bisa menyesuaikan aturan berdasarkan karakteristik dan kebutuhannya. Itulah mengapa jalur zonasi dan afirmasi ini secara eksplisit disebutkan proporsi minimal untuk memudahkan daerah dengan tetap dan atau menambah persentase jalur prestasi tersebut jika dibutuhkan.

Setelah menentukan kuota jalur Zonasi, kuota jalur afirmasi, dan seterusnya, daerah secara transparan harus menjelaskan ketentuan PPDB masing-masing kepada masyarakat, terutama pemangku kepentingan yang berkaitan dengan ketentuan ini. Pemerintah Daerah juga sebaiknya menjelaskan kepada publik latar belakang penetapan proporsi dari masing-masing jalur tersebut, sebagai bagian dari akuntabilitas dan transparansi kepada publik. Dinas Pendidikan juga diminta untuk melaporkan ketentuan yang dibuat serta pelaksanaan PPDB kepada Kemendikbud, agar bisa dilakukan monitor dan evaluasi pelaksanaan Permendikbud.

Perubahan ini dilakukan setelah mempelajari beragam implementasi PPDB pada tahun-tahun sebelumnya di tingkat Pemerintah daerah. Meskipun Permendikbud PPDB yang terdahulu (Permendikbud No 51 Tahun 2018 dan Permendikbud No 20 Tahun 2019) telah menetapkan secara tegas terkait persentase tiap jalur, namun dalam penerapannya Pemerintah Daerah membuat ketentuan PPDB utamanya pada jalur

\section{Mengapa perlu perubahan Permendikbud terkait PPDB?}


zonasi dengan mekanisme yang berbeda-beda, bahkan tidak sesuai dengan persentase minimal pada ketentuan PPDB sebelumnya. Hal ini mengindikasikan perlunya tinjauan ulang dalam membuat ketentuan yang agar dapat diterapkan daerah sesuai dengan kebutuhannya, dengan catatan daerah terus meningkatkan akses dan mutu pendidikan agar seluruh anak dapat belajar di sekolah yang bermutu.

\section{Bagaimana dengan daerah yang sudah menerapkan ketentuan Jalur Zonasi sebesar $\mathbf{8 0 \%}$ sesuai dengan Permendikbud PPDB sebelumnya (Permendikbud No 51 Tahun 2018, Permendikbud No 20 Tahun 2019)?}

Permendikbud PPDB yang baru ini tidak akan membuat ketentuan daerah yang sudah menerapkan jalur zonasi sebanyak $80 \%$ dengan tertib menjadi sia-sia. Pemerintah Pusat memberikan batas minimal $50 \%$ untuk setiap jalur penerimaan peserta didik baru, yang artinya Daerah yang sudah menerapkan jalur zonasi sebanyak $80 \%$, selanjutnya tinggal mengimplementasikan jalur lainnya sesuai dengan ketentuan Permendikbud terbaru tersebut.

Contoh penetapan jalur yang benar dan yang salah:

\begin{tabular}{|c|c|}
\hline $\begin{array}{l}\text { Penentuan Persentase Jalur } \\
\text { PPDB yang Benar }\end{array}$ & $\begin{array}{l}\text { Penentuan Persentase Jalur } \\
\text { PPDB yang Salah }\end{array}$ \\
\hline $\begin{array}{cc}\text { Kabupaten } \mathrm{A} \\
\text { - } & \text { Jalur zonasi } 50 \% \\
\text { - } & \text { Jalur afirmasi } 15 \% \\
\text { - } & \text { Jalur perpindahan } \\
& \text { orangtua/wali } 5 \% \\
\text { - } & \text { Jalur prestasi } 30 \% \\
\end{array}$ & \multirow{3}{*}{ 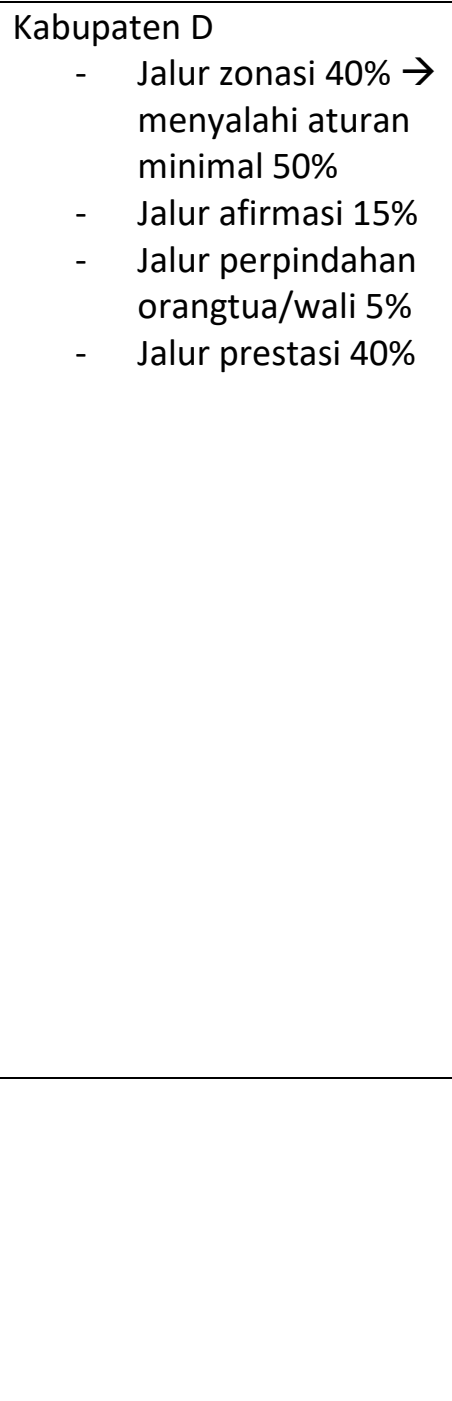 } \\
\hline $\begin{array}{l}\text { Kabupaten B } \\
\text { - } \quad \text { Jalur zonasi } 80 \% \\
\text { - } \quad \text { Jalur afirmasi } 15 \% \\
\text { - } \quad \text { Jalur perpindahan } \\
\quad \text { orangtua/wali } 5 \% \\
\text { Catatan: Pemda tidak } \\
\text { menetapkan jalur prestasi } \\
\text { karena sudah cukup } \\
\text { ditambahkan kedalam jalur } \\
\text { zonasi (jalur prestasi dalam } \\
\text { Permendikbud disebutkan } \\
\text { kata sisanya, tidak ada } \\
\text { ketentuan minimal, artinya } \\
\text { tidak wajib dilaksanakan jika } \\
\text { dapat disalurkan kepada } \\
\text { jalur zonasi, afirmasi, dan } \\
\text { perpindahan) }\end{array}$ & \\
\hline 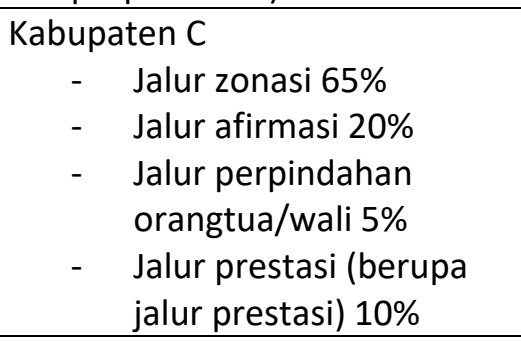 & \\
\hline
\end{tabular}


Jika yang bermasalah dalam mengatur PPDB adalah Pemerintah Daerah, mengapa Pemerintah Pusat perlu mengganti aturan?
Pemerintah Pusat tidak bisa menyeragamkan pengelolaan PPDB ini. Fungsi Pemerintah Pusat dalam hal ini adalah sebagai fasilitator, bukan sebagai regulator yang tidak memperhatikan kondisi dan kebutuhan di daerah. Pemerintah Pusat memfasilitasi Daerah untuk mengelola sistem pendidikan agar setiap anak di daerah tersebut dapat mengakses pendidikan bermutu, dan sistemnya lebih berkeadilan sosial. Dalam pelaksanaan evaluasi pelaksanaan PPDB di daerah, ditemukan bahwa Pemerintah Daerah kesulitan melakukan pemetaan jumlah usia anak sekolah yang sedang mengikuti PPDB dan jumlah daya tampung yang tersedia di Sekolah, sehingga dalam penerapannya cukup sulit dilaksanakan PPDB dengan jalur zonasi dengan persentase yang cukup besar. Oleh karena itu, Pemerintah Pusat sangat mengapresiasi Pemerintah Daerah yang telah mampu menghitung dan memenuhi daya tampung serta mutu yang baik merata di seluruh Sekolah. Oleh karena itu Pemerintah Pusat memberikan aturan yang lebih fleksibel kali ini, sembari mendorong Pemerintah Daerah untuk melakukan pemetaan dengan data yang tepat, meningkatkan akses melalui daya tampung Sekolah yang mencukupi, dan meningkatkan mutu pendidikan di setiap Sekolah agar kualitas pendidikan yang tinggi dapat dirasakan oleh seluruh anak Indonesia.
Mengapa Pemerintah Pusat menyarankan pelibatan sekolah swasta?
Data yang dikeluarkan Pusat Data dan Statistik Pendidikan dan Kebudayaan (PDSPK) menunjukkan bahwa jumlah sekolah negeri pada jenjang SMP lebih sedikit dibandingkan SMA, bahkan lebih dari $60 \%$ SMA adalah sekolah swasta. Membangun sekolah negeri baru untuk meningkatkan akses pendidikan bukan langkah yang ekonomis untuk dilakukan dalam waktu dekat. Setiap tahunnya, siswa yang lulus dan siap masuk SMA, tanpa menunggu proses pembangunan gedung sekolah. Rencana menambah jumlah sekolah negeri adalah rencana yang baik dan patut dilakukan pemerintah daerah. Namun selama ini sekolah yang diselenggarakan oleh masyarakat yang berbiaya rendah juga sangat berperan dalam membuka akses pendidikan, sehingga kemitraan dengan Dinas Pendidikan akan menjadi solusi yang baik bagi kedua belah pihak.

Dalam upaya pelibatan sekolah yang diselenggarakan oleh masyarakat, Pemerintah Daerah sebaiknya mempertimbangkan kualitas layanan di sekolah yang diselenggarakan oleh masyarakat, sebelum Pemerintah Daerah melibatkan sekolah tersebut dalam skema PPBD.

\section{Apa yang diharapkan Pemerintah Pusat dari Pemerintah Daerah, terkait dengan PPBD dan akses pendidikan?}

Dalam pelaksanaan PPDB melalui Jalur Zonasi yang sudah dilaksanakan sebelumnya, data menunjukkan bahwa jumlah daya tampung Sekolah Negeri tidak cukup untuk menerima seluruh siswa yang mendaftar pada Sekolah jenjang berikutnya melalui PPDB. Hal ini mendorong daerah memberikan intervensi dalam pemenuhan layanan pendidikan di daerahnya, karena pada dasarnya Pendidikan adalah 
Layanan Dasar sebagaimana ketentuan dalam UU Pemerintahan Daerah.

Memenuhi hak akses pendidikan perlu menjadi prioritas, namun perlu disadari bahwa membangun Unit Sekolah Negeri Baru memerlukan langkah yang cukup panjang dengan membutuhkan pembebasan lahan, durasi pembangunan yang lama, dan adanya keterbatasan anggaran negara. Sekolah Swasta dapat menjadi alternatif dalam pemenuhan daya tampung, juga sebagai bentuk kolaborasi antara Pemerintah dengan masyarakat. Kolaborasi ini dapat diupayakan sembari pemenuhan pendidikan utamanya bagi yang tidak mampu dipenuhi oleh Pemerintah Daerah, dapat berupa subsidi biaya, bantuan operasional, maupun mekanisme lainnya.

Mengapa tidak menyerahkan sepenuhnya saja kepada Daerah untuk mengelola PPDB?
PPDB jalur Zonasi yang diatur dalam Permendikbud yang baru bertujuan untuk meningkatkan akses pendidikan yang berkualitas tanpa diskriminasi. Selain itu, pendidikan yang bermutu adalah hak setiap anak Indonesia yang harus dipenuhi Pemerintah. Artinya, kualitas pendidikan harus merata. Oleh karena itu, untuk memastikan bahwa tujuan ini dapat dicapai, Pemerintah Pusat mengatur beberapa aturan dan batasan, yaitu dengan adanya jalur zonasi dan jalur afirmasi yang memiliki batasan minimal serta jalur perpindahan orang tua yang memiliki batasan maksimal untuk setiap jalur penerimaan peserta didik, dan apabila masih ada sisa dapat digunakan untuk jalur prestasi.

\section{Mengapa Pemerintah Daerah perlu melaporkan aturan dan hasil Pelaksanaan PPDB kepada Pemerintah Pusat?}

Pelaksanaan PPDB yang dilakukan Pemerintah Daerah penting untuk dilaporkan kepada Pemerintah Pusat, hal ini dikarenakan segala kebijakan PPDB yang diterapkan oleh Pemerintah Daerah adalah data bagi Pemerintah Pusat untuk memahami mekanisme pemenuhan akses pendidikan di daerah, dengan tantangan yang berbeda-beda sesuai dengan karakteristik daerah masing-masing. Melalui PPDB ini pun dapat dipetakan data pemenuhan akses anak terhadap pendidikan. Hal ini juga memudahkan Pemerintah Pusat dan Pemerintah Daerah dalam memberikan keputusan ketika menghadapi tantangan yang ada di sekolah sesuai dengan kebutuhannya masingmasing.

\author{
Terkait dengan \\ pengumuman kebijakan \\ PPDB, apakah informasi \\ ini perlu disampaikan \\ juga kepada warga \\ masyarakat walaupun \\ mereka tidak \\ berkepentingan secara \\ langsung dengan \\ penerimaan siswa baru?
}

Ya, pendidikan adalah tanggung jawab bersama, dan perlu menjadi perhatian seluruh warga masyarakat, tidak hanya orangtua yang mendaftarkan anaknya sekolah saja. Kepedulian masyarakat dapat mendorong pemerintah untuk meningkatkan pemerataan kesempatan untuk mendapatkan pendidikan yang berkualitas. 
Mengapa menggunakan batas minimum untuk jalur zonasi dan jalur afirmasi?
PPDB adalah suatu proses yang sangat perlu memperhatikan konteks lokal, misalnya berapa banyak sekolah negeri di suatu wilayah, berapa banyak anak usia SD yang akan melanjut ke SMP, serta dari SMP ke SMA, berapa banyak anak penerima Kartu Indonesia Pintar (KIP) di daerah tersebut, berapa banyak yang kondisi ruang kelasnya rusak, dan sebagainya. Akan lebih efisien, sesuai konteks, dan tepat sasaran apabila masing-masing Daerah yang mengatur regulasi PPDB yang disesuaikan dengan karakteristik dan kebutuhan masing-masing daerah. Hal ini juga selaras dengan semangat otonomi daerah, Pemerintah Pusat memberikan Norma, Standar, Pedoman, dan Kriteria sesuai dengan UU Pemerintahan Daerah sebagai ramburambu yang digunakan oleh Pemerintah Daerah.

\section{Apa yang dimaksud} dengan jalur afirmasi?
Jalur afirmasi disediakan untuk siswa yang menerima program penanganan keluarga tidak mampu dari Pemerintah Pusat atau Pemerintah Daerah (misalnya penerima KIP). Jalur ini merupakan komitmen Pemerintah Pusat dan Pemerintah Daerah untuk meningkatkan layanan akses pendidikan berkualitas untuk anak-anak dari keluarga tidak mampu. Pemerintah Daerah dapat menentukan proporsi siswa yang diterima melalui jalur ini dengan mengacu pada persentase siswa yang menerima program penanganan keluarga tidak mampu dari Pemerintah Pusat atau Pemerintah Daerah di daerah tersebut.

\section{Jika ada calon peserta didik penerima KIP namun secara domisili peserta didik yang bersangkutan juga bisa masuk melalui jalur zonasi, jalur mana yang akan diikutinya?}

Jalur afirmasi, jika kuota afirmasi belum terpenuhi untuk sekolah tersebut. Hal ini dilakukan agar siswa dalam zona yang tidak menerima program penanganan keluarga tidak mampu dari Pemerintah Pusat atau Pemerintah Daerah tidak terhalangi untuk masuk ke sekolah tersebut. Dengan demikian, kesempatan yang diberikan pemerintah pada siswa dari keluarga tidak mampu sedapat mungkin tidak merugikan siswa dari kelas sosial lainnya.

\section{Persentase minimum untuk jalur zonasi hanya $50 \%$, ini lebih kecil daripada proporsi di Permendikbud Nomor 51 Tahun 2018 tentang Penerimaan Peserta Didik Baru pada Taman Kanak-Kanak, Sekolah Dasar, Sekolah Menengah Pertama, Sekolah Menengah Atas, dan Sekolah Menengah Kejuruan sebagaimana diubah dengan}

Ada dua alasan utama terkait hal ini. Pertama, Pemerintah Pusat mendengar beberapa masukan dari Pemerintah Daerah untuk mencapai jalur zonasi dengan batas minimum $80 \%$ mengalami kesulitan. Karena khawatir tidak mencapai angka tersebut, satuan zona diperbesar. Bahkan wilayah satu kota menjadi satu zona, tidak dibagi menjadi beberapa zona karena khawatir ada sekolah yang tidak mendapatkan siswa. Jika satu zona sudah sebesar wilayah administrasi Dinas Pendidikan Kabupaten/Kota, maka esensi dari PPDB melalui jalur zonasi ini menjadi tidak jelas. Dengan adanya aturan yang tidak seketat dahulu, diharapkan Daerah lebih optimis bahwa tujuan PPDB melalui jalur zonasi ini dapat diwujudkan.

Kedua, yang tidak kalah pentingnya adalah masalah kondisi sekolah di Indonesia yang masih belum merata kualitasnya. Demikian pula penyebaran guru yang berkualitas tinggi juga masih belum merata. 
Permendikbud Nomor 20 Tahun 2019 tentang Perubahan atas Peraturan Menteri Pendidikan dan Kebudayaan Nomor 51 Tahun 2018 tentang Penerimaan Peserta Didik Baru pada Taman Kanak-Kanak, Sekolah Dasar, Sekolah Menengah Pertama, Sekolah Menengah Atas, dan Sekolah Menengah Kejuruan.

Apa pertimbangan Pemerintah Pusat tentang hal ini?
Menurut data terakhir Kemendikbud, ruang kelas yang kondisinya tergolong baik tidak mencapai 50\% di seluruh Indonesia. Artinya lebih banyak ruang kelas yang rusak dibandingkan yang baik. Pemerintah Daerah perlu melakukan berbagai upaya untuk mengatasi tentang masalah ini, begitu juga dengan akses pendidikan yang semakin sulit dicapai anak-anak miskin di jenjang yang lebih tinggi. Namun demikian, Pemerintah Daerah pasti perlu waktu untuk memperbaiki kondisi ruang kelas dan pendistribusian guru berkualitas, disisi lain siswa lulus dari sekolah setiap tahun tanpa henti, tidak bisa menunggu ruang kelas direnovasi atau guru berkualitas dirotasi. Maka jangan sampai kebijakan untuk pemerataan pendidikan mengorbankan anak.

\section{Apakah penurunan \% siswa yang masuk melalui sistem zonasi ini menandakan bahwa Pemerintah kurang berpihak pada anak-anak miskin yang biasanya hanya jadi "penonton" sekolah "favorit" di lingkungannya?}

Pemerintah terus berkomitmen pada pemerataan kualitas pendidikan, namun jangan sampai kebijakan tersebut mengorbankan anak. Asumsi bahwa dengan dibatasi wilayah maka anak miskin dapat mengakses pendidikan berkualitas juga belum tentu berlaku di semua wilayah. Tidak mustahil dengan adanya zonasi yang ketat anak-anak dari keluarga miskin yang berpotensi tinggi justru "terjebak" untuk masuk sekolah yang ada di dekat rumahnya, yang sebenarnya kualitasnya kurang baik. Namun ini semua masih berlandaskan asumsi, kita perlu data empiris dan analisis yang lebih sistematis untuk memastikan bahwa aturan PPDB tidak merugikan kelompok tertentu.

Kedua, secara eksplisit ada jalur afirmasi yang disyaratkan oleh Pemerintah Pusat. Hal ini menunjukkan komitmen pada pemerataan kesempatan pendidikan untuk anak-anak dari keluarga tidak mampu.
Apakah penurunan \% zonasi ini menandakan bahwa "sekolah favorit" akan dipertahankan?
Tidak, pertimbangan tentang batas minimum jalur zonasi dan jalur afirmasi tidak ada hubungannya dengan favoritisme. Sebelum kebijakan zonasi diterapkan, kita tidak bisa benar-benar mengatakan bahwa ada sekolah unggulan karena yang unggul adalah input siswanya. Mereka sudah tersaring ketat, sehingga di suatu sekolah yang mendapat label "unggulan" atau "favorit" ini siswanya cenderung homogen, yaitu mayoritas siswa dengan capaian akademik yang tinggi. Karena umumnya mereka dari keluarga kelas menengah sampai dengan kelas atas, dukungan belajar di luar sekolah untuk anak-anak ini juga lebih baik, misalnya ikut Bimbingan Belajar, kursus bahasa asing, dan sebagainya. Sehingga output dari sekolah itu pun menjadi unggulan. Kita ingin semua sekolah unggul, sama baiknya. Setiap anak mendapat kesempatan belajar di ruang kelas yang baik kondisinya dan diajar oleh guru yang kompeten. Sebelum kebijakan zonasi diterapkan, hanya siswa tertentu saja yang berkesempatan 
demikian. Pemerintah, baik Pusat maupun Daerah, tidak boleh membuat aturan yang mendiskriminasi kelompok tertentu.

Mengapa jalur prestasi disediakan maksimal $30 \%$ saja?
Kembali ke tujuan besar dari PPDB adalah untuk pemerataan

kesempatan pendidikan, di mana akses terbuka untuk semua anak, maka jalur prestasi yang terlalu besar bisa menjauhkan kita dari tujuan tersebut. Daerah tidak harus membuka jalur ini, karena mungkin akses sekolah sudah sangat besar dari segi suplai, maka semua anak dalam zona sudah bisa tertampung.

\section{Satuan wilayah zonasi}

Apakah ada perubahan peraturan terkait penghitungan satuan wilayah zonasi?
Pemerintah Daerah perlu menetapkan satuan wilayah zonasi, seberapa luasnya serta berapa banyak wilayah zonasi yang ada di wilayah administrasinya. Hal ini dilakukan dengan cara memetakan jumlah dan domisili calon peserta didik baru, daya tampung sekolah, dan jumlah sekolah yang diselenggarakan masyarakat yang akan disertakan dan sekolah yang berbasis agama. Data ini seharusnya ada di tingkat daerah.
Ada kasus di mana anak tinggal di wilayah perbatasan, harus masuk ke sekolah yang lebih jauh karena masuk dalam zonanya. Padahal lebih dekat jika bersekolah di zona yang berbeda.

Kasus ini sudah ada jalan keluarnya?
Ini adalah hal yang perlu diperhitungkan Pemerintah Daerah ketika membuat zona. Harusnya kasus seperti ini tidak banyak, karena jika banyak artinya metode penetapan zonanya keliru. Oleh karena tidak banyak, hal-hal seperti ini seharusnya bisa diselesaikan Pemerintah Daerah, melalui musyawarah yang hasilnya demi kebaikan anak.

\section{Dampak PPDB saat ini}

\section{Sistem PPDB saat ini menyebabkan guru kesulitan mengajar karena capaian akademik siswanya terlalu beragam. Sebaiknya apa yang dilakukan sekolah?}

Ketika PPDB berlandaskan pada hasil tes, sekolah memang lebih homogen. Menjadi tidak adil ketika terdapat sekolah homogen yang mayoritas siswanya siap belajar dan orangtua mereka siap untuk mendukung anak belajar, sementara di sekolah lainnya berkumpul siswa dengan kondisi yang sebaliknya.

Guru yang efektif adalah guru yang mampu menggunakan berbagai strategi dan pendekatan dalam mengajar anak-anak dengan kemampuan yang berbeda-beda. Salah satu hal yang bisa dilakukan adalah meningkatkan kapasitas guru-guru dalam menggunakan pendekatan yang beragam (differentiated instruction). Mendidik semua anak tanpa diskriminasi adalah tugas setiap satuan pendidikan. 
Prinsip ini berlaku untuk semua, pemerintah pusat, daerah, sekolah dan juga guru.

PPDB melahirkan

kecurangan baru, yaitu

manipulasi Kartu

Keluarga agar anak bisa memasuki sekolah unggulan. Bagaimana jalan keluarnya?
Dengan aturan yang lebih fleksibel, diharapkan praktik seperti ini tidak lagi terjadi karena tidak ada lagi anak yang tidak mendapatkan sekolah.

Harapan orangtua dan anak untuk bisa masuk sekolah tertentu terjadi ketika kualitas pendidikan tidak merata. Maka dengan perubahan sistem PPDB ini, pemerataan kualitas belajar di seluruh sekolah menjadi prioritas pemerintah baik di pusat maupun di daerah. Maka dalam jangka menengah dan jangka panjang, harapannya tidak ada lagi orangtua yang menggunakan cara yang melanggar aturan dalam mendaftarkan anaknya karena kualitas sekolah sama baiknya.
Dan ada juga praktik "jual-beli bangku" di sekolah favorit, bagaimana mengatasinya?
Praktik ini sebenarnya sudah lama sering terjadi, bukan ketika diterapkan aturan zonasi saja. Hal ini merupakan masalah korupsi di sekolah secara umum. Praktik ini sudah ada baik ketika PPDB sepenuhnya jalur seleksi (sebelum ada aturan zonasi) maupun saat diterapkannya zonasi. Kita perlu kebijakan lain terkait penanggulangan korupsi untuk menghentikan praktik-praktik ini.

Dari empat jalur PPDB, salah satunya adalah jalur prestasi. Untuk jalur ini kriteria seleksi dapat menggunakan nilai Ujian Nasional. Sehingga tidak ada yang bertentangan dengan PP tersebut. menggunakan nilai Ujian

Nasional. Tidakkah ini

bertentangan dengan

Pasal 68 huruf b PP SNP

yang menyatakan bahwa hasil ujian nasional digunakan untuk seleksi masuk jenjang pendidikan berikutnya? 